Мирослава Шевченко

аспірантка

Інститут проблем сучасного мистецтва

НАМ України
Myroslava Shevchenko

postgraduate student

Modern Art Research Institute

of the National Academy of Arts of Ukraine

e-mail: 13myroart@gmail.comｏrcid.org/0000-0002-4243-024X

\title{
ІНТЕРПРЕТАЦІЯ ТРАДИЦІЙ УКРАЇНСЬКОЇ КУЛЬТУРИ У ТВОРЧОСТІ ХУДОЖНИКІВ ПОЧАТКУ ХХ СТОЛІТТЯ: ҐЕНЕЗА НАЦІОНАЛЬНОГО СТИЛЮ У МИСТЕЦТВІ
}

\author{
Interpreting the Traditions of Ukrainian Culture \\ in the Works of the Early 20th Century Artists: \\ Genesis of the National Style in Art
}

\begin{abstract}
Анотація. Розглянуто питання генези національного стилю в українському мистецтві початку XX століття. Виявлено теми, до яких зверталися художники, розкриваючи свій творчий потенціал. Проаналізовано твори, що увиразнюють нові стильові прояви у мистецтві, охарактеризовано світоглядні засади та творчу манеру митців в інтерпретації традицій української культури, зокрема народного мистецтва, у контексті формування національного стилю.

Ключові слова: український національний стиль, народне мистецтво, українська культура, живопис, графіка, ХХ століття.
\end{abstract}

Постановка проблеми та актуальність дослідження. Одним із важливих питань сучасної мистецтвознавчої науки є оцінка ролі традицій української культури у творчості художників першої третини XX століття, які прагнули виразити суть національного буття у новій модерній формі.

В умовах стрімкого розвитку сучасного українського мистецтва осмислення культурного надбання XX століття $є$ нагальним у контексті розуміння художніх процесів та їхньої верифікації відповідно до культурної ситуації. XX сторіччя позначене насамперед періодом «національного відродження", яке формувало подальший курс розвитку українського мистецтва. У роки революцій та воєн існували різноманітні течії та напрями у мистецтві. Митці, об'єднані ідеєю творення українського мистецтва, мали на меті свідомо чи підсвідомо відродити і формувати нові засади національного мистецтва. Сенсом мистецького руху першої третини XX століття було творення національного за мовою, формою та змістом мистецтва. Варто сказати, що для кожного художника цей шлях був свій, умови реалізації цього задуму також відрізнялися. Але всі з перелічених далі художників - М. Бойчук, брати Кричевські, Г. Нарбут, О. Мурашко, О. Новаківський, М. Сосенко, I. Северин, Ф. Красицький, М. Івасюк, О. Самокиш, А. Ждаха, М. Жук, А. Маневич, М. Бурачек; на Галичині: А. Монастирський, О. Курилас, Ю. Буцманюк, О. Кульчицька, І. Іванець, П. Оба- ль, Л. Гец, О. Сорохтей, Й. Бокшай та інші - виявляли традиції української культури у своїй творчості та фокусувалися на відродженні української теми.

Аналіз останніх досліджень і публікацій. Публікації фахівців, від сучасників того періоду і дотепер, свідчать, що українська тема в творчості художників була і є актуальною. У працях вітчизняних науковців Л. Соколюк, Г. Скляренко, О. Федорука, Я. Кравченка, В. Рубан-Кричевської, О. Лагутенко, Л. Смирної, М. Юр та інших розглянуто та досліджено період початку XX століття. На темі національного стилю в мистецтві початку XX століття особливо зосереджувалася Л. Соколюк. Але обсяг матеріалу, що підлягає дослідженню та вивченню, значний, тому деякі аспекти досліджені не повністю.

Формулювання мети. Важливо дослідити проблему формування українського національного мистецтва на початку XX століття та роль у цьому народного мистецтва, що впливало на світогляд художників, у діяльності яких увиразнено націєтворчий потенціал мистецтва. Досі цілісно не досліджувалася генеза національного стилю у творчості художників першої третини XX століття.

Виклад основного матеріалу. У статті здійснено спробу проаналізувати інтерпретації традицій української культури у творчості українських художників та виявити основні джерела їхньої творчості. 
Джерельна база дослідження включає декілька видів інформаційних матеріалів: періодичні видання різних років (1918-2017 роки); документальні матеріали, а саме: періодичні видання, спогади, листи, монографії різних років, каталоги виставок, архіви та фонди бібліотек i музеїв; репродукції та оригінали творів художників.

Кінець XVII і майже все XIX століття $є$ епохою занепаду і денаціоналізації українського малярства. Про українське малярство Микола Голубець пише: «Українські малярі Лосенко, Левицький, Боровиковський “ідуть служити чужим богам, а мистецькі вимоги України заспокоюються чужинецькими партачами” " [5, c. 30]. В цей час техніка починає домінувати над змістом: в картині "мистецтво будується на засаді “як”, а не “що”" [2, с. 73].

Наприкінці XIX століття істотно розвиненим був іконопис та народне мистецтво: дерев'яне будівництво, різьблення по дереву, кераміка. На початку ХХ століття інтерес до народного та українського мистецтва загалом істотно зріс. Про це пише Вадим Щербаківський ще в 1913 році: «За останні часи значно побільшився інтерес до народного мистецтва 3 осібна до мистецтва українського» [17, с. 3].

Якщо проаналізувати твори художників початку XX століття, то вплив саме народного мистецтва на їхню творчість був значним, зокрема цей вплив відчувається у творах художників Василя та Федора Кричевських (в яких елементи народного мистецтва присутні і в архітектурі, і в малярстві, і в графіці), Г. Нарбута, М. Бойчука та інших. Початок минулого століття ознаменувався піднесенням національної свідомості та духу українського народу. «В останнє десятиліття XIX століття починається живіший рух у відродженні українського малярства, слабо, але безустанно» [5, c. 30].

ХХ століття для України - це період важких випробувань, суспільно-політичних подій, злетів та падінь. Попри цензуру, яка забороняла та обмежувала вживання рідної мови, прогресивні діячі відстоювали право на навчання в школах та видання підручників українською мовою. Завдяки активній діяльності «Просвіт» в період революції 1905-1907 років на теренах України видавали літературу, читали лекції українською мовою та відкривали бібліотеки. Впливовими журналами 3 дослідження етнографії, археології, історії були «Киевская старина», «Літературно-науковий вісник» та "Українська хата». У період Центральної Ради, з 1917 року, почалася українізація освіти та підтримка української культури державою. 3 народженням Української Народної Республіки відбулася значна подія в культурному і мистецькому житті XX століття - заснування Української Академії Мистецтв в 1917 році (нині - Національна академія образотворчого мистецтва і архітектури) за системою вільних індивідуальних майстерень. Ініціаторами були найпрогресивніші діячі культури, науки та мистецтва: «Академік
Михайло Грушевський, вчені Дмитро Антонович і Григорій Павлуцький, художник Василь Кричевський, Федір Кричевський, Вадим Меллер, Михайло Бойчук, Олександр Мурашко, Георгій Нарбут, Микола Бурачек, Михайло Жук, Абрам Маневич» [8, с. 1].

Ця подія дала змогу експериментувати та творити на теренах своєї держави. Спільною ідеєю засновників та викладачів було поєднати «давні національні традиції мистецтва 3 новими течіями європейського мистецтва» [15, с. 64]. Академія надала студентам творче підгрунтя та заклала глобальне бачення художнього вираження як за формою, так і за змістом, а викладачам сприяла у творчому розвитку та пошуку нових форм, змісту, бачення.

Початок ХХ століття - це період формування мистецтвознавчої науки. Все частіше з'являються мистецтвознавчі статті, серед них - мистецько-критичні праці М. Мурашка, М. Бурачека. Дослідженню та висвітленню проблем народного мистецтва приділили особливу увагу Д. Яворницький, М. Біляшівський та М. Макаренко. За редакцією І. Труша та С. Людкевича з 1905 року виходив «Артистичний вісник». А 1907 рік відзначився появою у Києві значної кількості мистецтвознавчих видань. Революційна хвиля 1905-1907 років зумовила розвиток мистецтва графіки, а саме сатири, такі малюнки наповнювали як російські, так і українські видання.

Мистецтво першої половини ХХ століття сповнене фундаментальних постатей, які формували національний стиль, кожен у своїй індивідуальній манері. Утім, цього не можна сказати про М. Бойчука та його послідовників, чия творчість часто була колективною. Бойчукісти продовжили започаткований М. Бойчуком український національний стиль, керуючись настановами фундатора. Школа намагалася об'єднати архітектуру та різні форми мистецької діяльності.

Відродження України в XX столітті супроводжувалося загостренням проблеми національної самоідентифікації та стихійним формуванням концепцій «українського стилю». Початок XX століття - період розквіту та творчого піднесення, це також період різноманітності художніх стилів та напрямів. Про це зазначає I. Врона: “оригінальність і самобутність” не стали приналежністю всього тогочасного українського мистецтва, бо в ньому перепліталися “найрізноманітніші й численні течії, напрямки і школи”, стиналися “різноманітні і суперечливі тенденції і впливи”» [4, с. 60].

Поряд із професійними художниками в ті часи паралельно працювали і видатні постаті, які розвивали традиції українського народного мистецтва: I. Гончар, Г. Собачко-Шостак, М. Приймаченко, П. Власенко та інші майстри. Їхнє самобутнє мистецтво втілює основи прадавньої глибинної народної культури і виражає неповторну національну своєрідність. До творів цих художників зверталися художники-авангардисти, модерністи. 
Основоположниками національного стилю минулого століття були художники М. Бойчук, Василь та Федір Кричевські, Г. Нарбут, Я. Струхманчук, а розвивали ці ідеї О. Сластіон, М. Бурачек, І. Їжакевич, Ф. Красицький, О. Саєнко, С. Налепинська-Бойчук, І. Падалка, В. Седляр, О. Павленко, Т. Бойчук, В. Бура-Мацапура, В. Вейланд, П. Іванченко, М. Рокицький, М. Холодна, М. Юнак, М. Самокиш, Г. Світлицький, К. Трохименко, О. Шовкуненко, П. Волокидін, І. Труш, О. Новаківський, С. Прохоров. Специфічного забарвлення стилеві М. Бойчука та усій його школі надавала тематико-сюжетна типологія: вони часто зображували українське селянство, оспівуючи його працю, монументалізуючи образи [16, с. 1].

М. Бойчуку були притаманні пошуки у витоках народного мистецтва, вплив якого прочитується в його творах «Урожай (збирання яблук)» (1910-ті роки), «Катерина» (початок 1910-х), «Українка» (початок 1910-х). Автор звертався до української теми як основи сюжету творів: «Проект пам'ятника Т. Г. Шевченка» (прибл. 1914 рік), плакат «Шевченківське свято» (1920) та інших. Як і М. Бойчук, $\Phi$. Кричевський виявляв у творах національні мистецькі форми та елементи форм: «Наречена» (1910), «Три віки» (1913), «Життя», у триптиху «Любов. Сім’я. Повернення» (1927), «Т. Шевченко» (1929), «Довбуш» (1931), циклі картин за поемою Т. Шевченка «Катерина» (1937-1940) («Замріяна Катерина»).

Перший, хто втілив ідею українського національного стилю в архітектурі, був В. Кричевський. За проектом архітектора було споруджено: будинок Полтавського губернського земства (1903-1908), будинок I. І. Щітківського (1907-1908), будинок гончарного навчальнопоказового пункту Полтавського губернського земства (1916-1919), Меморіальний будинок-музей Т. Шевченка в Києві (19231924), де автор спирався на традиції народного будівництва та декоративно-ужиткового мистецтва України. Основою його творчості було народне мистецтво. Унікальними за своїм поєднанням є стильові прояви Г. Нарбута: графічний силует, шрифтові композиції та геральдичні знаки, символи та орнаментика утворюють неповторний стиль, який втілює інтерпретації традицій української культури, зокрема народного мистецтва. Основою більшості творів Нарбута $€$ український образотворчий фольклор: «Українська абетка" (1917), «Малюнок до "Енеїди” (1919), заставки 3 журналу «Мистецтво» (1919), «Портрет Б. Хмельницького». Вони творили «чисте» українське мистецтво часто інтуїтивно, звертаючись підсвідомо до свого коріння, не інтерпретуючи чужих ідей. Таке мистецтво і є галуззю культури, що $є$ «показчиком культуральної височини, якої досягла певна нація» [2, с. 66].

Об'єднані ідеєю створення та відродження української форми (теми, колористики) у творах, митці виражали ії̈ у різних видах та жанpax мистецтва. «Стінопись, стінна і переносна мозаїка, іконопись, мініятура, емаль, дереворит, гравюра, історичні і побутові композиції, краєвид та портрет розвинулося, як на наші умови, доволі високо", - характеризує жанри, види стан і рівень мистецтва, мистецтвознавець Микола Голубець у 1918 році, а «тяглість та стилева послідовність від софійських фресок та мозаїк до полотен Новаківського» [5, с. 20].

«Українці за походженням, такі, як Трутовський, Пимоненко, Ярошенко, Рєпін вони хоч і малювали Україну, але дивилися на неї чужими очима", - так роздумує М. Голубець над внутрішньою єдністю цих художників з українством [5, с. 30]. Автор не намагався применшити значення перелічених художників у мистецтві. Вони присвятили багато творів Україні, але розвиток національного стилю не був їхньою ціллю. Тематикою творчості, як М. Пимоненка, так і К. Трутовського, $€$ високопрофесійне, душевне, настроєве та максимально точне відтворення побуту українського народу, звичаїв, обрядів, що $є$ інтерпретацією українських традицій у творчості художника. Через побутовий жанр художники намагалися висвітлити тогочасні соціальні проблеми. Найвиразніше ці теми М. Пимоненко зобразив у творах «Ярмарок», «Додому», «Гопак», «Весілля в Київській губернії», «Конокрад», «Збирання сіна», «Жертва фанатизму», «Проводи рекрутів» та ін.

Відродження українського малярства можна розглядати від "більш свідомих" митців, таких як Сластіон, Васильківський, брати Кричевські (Устиянович, Панькевич - на Галичині). «Вони були першими, що з більшим чи меншим успіхом, але з ясною метою, старалися нав'язати нитку традиції українського малярства і розуміли що їня сила невигасаєма лише в тісній злуці з мистецьким змаганням українського народу", - так про цих митців говорить Микола Голубець [5, с. 34].

Культурний розвиток України 1920-х один із визначних феноменів української історії, а надто з огляду на ситуацію в країні, яка пережила революційні події, війну, потребувала відновлення, як економіки, так і інших вкрай важливих сфер. Феноменальним був культурний злет, який дав потужні плоди у розвитку національного мистецтва. Починаючи зі свого XII з'їзду (1923), Комуністична партія починає процес "українізації» з метою завоювати ширшу підтримку інтелігенції, культурних діячів та селянства. На цій хвилі розпочинається підтримка української культури, але, як показав час, ця «підтримка» була лише приманкою для культурних діячів. Це призвело до тимчасового розквіту культурного життя. Та невдовзі сталінський терор поклав цьому край. Утім, за цей недовгий час так званого відродження відбулася достатня кількість надважливих подій та становлення нових митців, які інтерпретували традиції української культури у своїй творчості. Період "українізації» ознаменувався різноманіттям стилів і утворенням нових художніх груп: 
АРМУ (Асоціація революційного мистецтва України), АХЧУ (Асоціація художників Червоної України), ОСМУ (Об’єднання сучасних митців України), ОММУ (Об’єднання молодих митців України) та багатьох інших.

Важливим моментом в реорганізації Академії Мистецтв (1924) був відхід від «застарілих “академічних" шаблонів і будування на нових педагогічно-мистецьких засадах". На малярському факультеті уникали гегемонії однієї якоїсь течії чи напряму, що невдовзі, з приходом соцреалізму, стане неможливим. Загальноєвропейські напрями в Академії Мистецтв вказують на свободу вибору. В. Січинський стверджував: «На малярському факультеті існує декілька угрупувань від імпресіоністичного реалізму до композиційного монументалізму, пост-сезанізму та “течії матеріальної культури”» - цей перелік течій дає зрозуміти, що свобода вибору в той час існувала. Окрім реорганізації методики навчання в академії, значною подією було заснування в 1924 році поліграфічного факультету, який виник з графічного відділу, що ним свого часу керував Г. Нарбут - найвидатніший український графік минулого століття [13, с. 52].

Ще 3 юних років Г. Нарбут копіював визначні пам'ятки стародруків, «заставки та віньєтки Остромирового євангеліє, біблії», перемальовуючи гравюри та заголовки, цілком передаючи характер техніки. Він копіює старослов’янські тексти, такі як «Слово о Полку Ігоревім», «Вчення Володимира Мономаха», переписуючи велику кількість аркушів. Згодом ці навички будуть використані у творчих пошуках художника. Митець звертався до лаврських стародруків, досліджував їхню техніку, вивчав українські тканини та вишивку, скуповував епінальські картини, захоплювався японськими та хінськими ксилографіями, порцеляною, а згодом, в 1913 році, - гербами і геральдичними емблемами. Міцна і глибока була національна стихія у Нарбута, і яскраво проступає вона у всіх його творах. За словами Ю. Михайліва, «Нарбут вкладав в кожну композицію питомі українські елементи, наділяючи її своєрідним гумором» [11]. Але захоплюючись різними художниками, він вивчав лише техніку, щоб потім створювати власні композиції. Він мав власне "начало», яке згодом дало блискучі результати.

Казки, байки, прислів'я - теми, які Г. Нарбут брав для роботи. Для кустарної майстерні «Іграшка" проектує забаву «Козак Мамай». Книга стала для нього альфою та омегою виявлення його мистецьких здібностей. Його стиль різко відокремлює його від інших графіків завдяки вродженому таланту і наполегливій праці [11, с. 79-92].

3 колосальними планами відродження рідної мистецької культури Нарбут у 1917 році покидає Петербург, де вчився, назавжди. Створює "Абетку", яку почав ще в Петербурзі, згодом досліджує Гетьманщину і козаччину. Визначним його твором, як тоді, так і зараз, $€$ «Енеїда». Вагомим внеском в українську культуру був розроблений художником у 1918 році герб Української держави. Патріотизмом позначена творчість художника воєнних років. «Я Московщину не люблю, хочу оддати Україні всі свої сили», - Нарбут про ставлення до України і відданість їй [14, с. 32]. Він залишив після себе послідовників, а українську книгу вивів на рівень найкращих європейських видань. «Учні: Лесь Лозовський, Марко Кірнарський, Роберт Лісовський, Леонід Хижинський, Павло Ковжун, Левандовський, Пажорський» [11, с. 72]. Творча спадщина митця $€$ дуже цінною для усвідомлення інтерпретацій української культури у його творах.

1926 рік ознаменувався проведенням великої кількості виставок, присвячених графіці і мистецтву книги, що вказувало на значний розвиток цього мистецтва. Відродження нової української гравюри, мистецтва книги, розвиток національної культури були одними з провідних завдань мистецтва графіки. Щоб будувати нове українське мистецтво, запрошували кваліфікованих чужих майстрів, здебільшого з Росії [7, с. 110].

До складу професорів Академії Мистецтв 1926 року входили: Василь і Фотій Кричевські, М. Бойчук, В. Мелер, Л. Крамаренко, А. Таран, А. Кратко, Є. Сагайдачний, С. НалепинськаБойчук, В. Татлін, В. Пальмов, С. Бернштайн, М. Козік, Колос, різьбярі Шермаїлов, Єпштайн, графіки С. Середа (декан факультету), О. Усачов, Плешинський, архітектори Альошин, Риков, Вербицький, Писаренко, Даміловський, Сакулін. Наставництво видатних художників, які направляли студентів Української Академії Мистецтв, справило на останніх неабиякий вплив, стимулювало творчі пошуки, «також викладання історії українського мистецтва було обов'язковим для всіх факультетів» [13, c. 53].

Важливими для розуміння втілення української традиційної культури в творчості $€$ художні та ідейні пошуки Василя Крижанівського (початок XX століття), про що пише О. Ковжун: «Особливо гаряче, останні роки життя В. Крижанівський шукав не лише стиль, форми, колористику, а українську форму, український стиль та українського ритму кольору, шукав за джерелами українського мистецтва", акцентуючи саме на національному стилі. Художник має осягти не лише зовнішню сторону малярства (грамотно побудувати композицію зі знанням колористики, вміло це застосувати у життєвому, історичному, романтично-сентиментальному сюжеті), а й внутрішню. Тією внутрішньою стороною українського образотворчого мистецтва є український дух і фактура, українська форма і властивий ритм $[10$, с. 64]. Зверталися до основ українського бароко як В. Крижанівський, так і Г. Нарбут, але перший не зупинився на українському бароко, а заглибився у візантійське мистецтво, яке його захопило цілком і стало джерелом його творчості.

Одним із найголовніших постатей XX століття вважають М. Бойчука - новатора мис- 
тецької концепції, засновника самобутньої школи монументального мистецтва, що з'явилася в Україні в першій третині минулого століття. Бойчук - один із засновників Української державної академії мистецтв (1917) та співорганізатор АРМУ (1925). Його творчість базувалася на «українських традиціях та західних зразках, він шукав натхнення у середньовічних фресках та іконах, народному мистецтві, мистецтві Візантії та картинах Італійського відродження" [6, с. 26].

Художник ознайомився 3 творчістю Сезанна, Ренуара, Пікассо, але не захоплювався ними. Його не привабило мистецьке життя, яке він бачив у Парижі, коли твори майстрів оберталися «на ринковий крам, на речі спекуляції, в руках у торговців, що обслуговували багачів-меценатів", - писав художник з часом. Через ідеї колективної творчості М. Бойчук прийшов до ідеї монументалізму. Група митців, що об'єдналася під його керівництвом (М. Касперович, С. Бодуен-де-Куртене, С. Налепинська), спромоглася на авторське самозречення. Такі “жертви» прийме не кожен художник, побоюючись втратити себе як індивідуальність. Але своїх учнів М. Бойчук переконував: «Не бійтеся втратити свою індивідуальність. Хто краще працює, до того й приглядайтеся. Не треба боятися запозичувать у іншого, - треба намагатися зробити краще... Iндивідуальність сама виявиться коли майстер визріє...» [1, с. 22-23].

Школу М. Бойчука продовжили В. Седляр, I. Падалка, О. Павленко, Т. Бойчук, С. Налепинська-Бойчук, А. Іванов, М. Шехтман, М. Рокицький, О. Саєнко, Т. Бойчук, В. Бура-Мацапура, В. Вейланд, П. Іванченко, М. Рокицький, М. Холодна, М. Юнак та інші. Це ті митці, які свідомо взяли на себе відповідальність відроджувати українську культуру.

Через трансформацію українського народного мистецтва і давніх культур різних народів М. Бойчук викарбував свій неординарний стиль. Взявшись за тему врожаю після голодомору 1932-1933 років, художник декламував «вітаїстичну» ідею народного безсмертя найголовнішу ідею Нарбута, Хвильового, Тичини. М. Бойчук: «Хто боїться підпасти під вплив минулого не розуміє основної сили нашої доби» [1, с. 22-24]. За спробу ввести до державних замовлень українські мотиви Бойчука, багатьох його колег та дружину було звинувачено в націоналізмі, згодом заарештовано, а в 1937 році страчено [6, с. 26].

Твори нищили, архіви не збереглися, але «уроки творення нового національного мистецтва стали Заповітом митця України на всі часи» [9, с. 57].

3 того, що дійшло до нашого часу, можна зробити висновок, що М. Бойчук творив мистецтво національне, як за формою, так за змістом, лишивши значний слід в українській культурі.

У певному розумінні конкурентами та колегами М. Бойчука були Василь та Федір Кричевські. Василь відродив «тип української гро- мадської споруди, звівши будинок Полтавського губернського земства на початку XX століття - український модерн, в якому досконало поєдналися елементи старовинних дерев’яних будівель 3 декором керамічних і майолікових орнаментів». Те, що завжди було традиційним народним мистецтвом, В. Кричевський трансформував в нову, модернову архітектуру, надав нового дихання традиційному мистецтву [9, с. 46]. Ця будівля класичний приклад втілення ідей "українського стилю». В той період орнаментика українська почала домінувати і в розписах, як стверджує Микола Голубець: «В розписах українських храмів чи світських будівель вже починається свідоме використання усіх багатств української орнаментики, краси української природи і життя» [5, с. 31]. В. Кричевський, надихаючись скарбами графіки XVIIXVIII століть, у своїй творчості давав їй нове життя, підкреслюючи їі естетичні риси.

Непересічна постать і О. Кульчицької, яка була однією з перших, хто звернувся до ужиткового мистецтва, вікових джерел народної творчості, а отже - до витоків, коріння українства, «бажаючи відродити його з еклектики та рутини міщанських смаків». Вона оздоблює орнаментальними мотивами, використовуючи стилістику народного мистецтва, конструктивні форми - предмети сучасного побуту. «Саме в синтезі сучасної естетики та нових форм побуту з духом вікової народної формотворчості мисткиня вбачала новий стиль часу». Національний стиль для художниці був пріоритетним. Мистецький доробок, а це естампна та книжкова графіка, малярство, ужиткове мистецтво, репрезентує своєрідний, глибоко національний за формою та змістом український варіант загальноєвропейського модерну [3, с. 47-49]. Інші художники - А. Петрицький та Д. Бурлюк пишуть картини у жвавому козацькому бароковому стилі, з духом монументальності, підсилених традиційною культурною спадщиною, у яких відбивається політичне напруження 1920-х років [12, с. 32].

Висновки. Мистецька спадщина художників, які згадувалися в дослідженні, є відображенням доби. Форма є відображенням часу. Ознаки відображаються в усі роки і періоди, а стилістика відображає час. Виявити національну форму можна лише через ознаки. Основними національними ознаками є інтерпретація народного мистецтва, відтворення у творах українського фольклору, побуту, звичаїв, обрядів, образу Т. Г. Шевченка. Митець тоді є національним, коли визнає свою належність до певної нації і творить за національною формою. Національний напрям став одним із головних в українському мистецтві періоду модерну. Національні ознаки відбиваються в національній формі.

У розвідці об’єднано українських художників М. Бойчука, Василя та Федора Кричевських, Г. Нарбута, Я. Струхманчука, О. Сластіона, М. Бурачека, Ф. Красицького, О. Саєнка, 
С. Налепинську-Бойчук, I. Падалку, В. Седляра, О. Павленко, Т. Бойчука, В. Буру-Мацапуру, В. Вейланд, П. Іванченка, М. Рокицького, М. Холодну, М. Юнак, М. Самокиша, Г. Світлицького, К. Трохименка, О. Шовкуненка, П. Волокидіна, I. Труша, О. Новаківського, М. Сосенка, М. Івасюка, М. Жука, А. Маневича, А. Монастир- ського, О. Куриласа, Ю. Буцманюка, О. Кульчицьку, І. Іванця, П. Обаль, Л. Гец, Й. Бокшая, які у творах репрезентували національний контент. Кожен з них виявив елементи самоідентифікації: в монументальному живописі, станковій чи книжковій графіці, розробці текстилю, деревообробці, вибійці, архітектурі.

\section{Література}

1. Білокінь С. Колективізм - пафос творчості Михайла Бойчука // Образотворче мистецтво. 1988. № 1. С. 22-24.

2. Бурачек М. Колєктивна творчість і шляхи національного мистецтва // Мистецтво. 1920. № 1. C. $64-81$.

3. Волошин Л. Творці українського модерну: Олена Кульчицька // Образотворче мистецтво. 2005. № 4. С. 47-49.

4. Врона И. Пути современного украинского искусства // Революция и культура. 1928. № 13. С. 60. 5. Голубець М. Малярство // Українське мистецтво. Львів; Київ: Шляхи, 1918. С. 36.

6. Зельська-Даревич Д. Українські культура і мистецтво крізь віки // Український модернізм: 19101930. Хмельницький: Галерея, 2006. С. 16-30.

7. Ернст Ф. Виставка рисунку і гравюри // Бібліологічні вісті. 1926. № 4. С. 110-111.

8. Прибєга Л. Віхи історії та сьогодення HAOMA. URL: http://naoma.edu.ua/ua/academy/storya/ (дата звернення: 01.06.2019).

9. Ковальська Л. Михайло Бойчук - учитель та митець // Український модернізм 1910-1930. Хмельницький: Галерея, 2006. С. 46-57.

10. Ковжун О. Василь Крижанівський 1891-1926 // Українське мистецтво. Львів; Київ: [б. в.], 1926. Ч. 3. С. $63-68$.

11. Михайлів Ю. Георгій Нарбут // Життя й революція. 1926. № 10. С. 79-92.

12. Мудрак М. Український авангард // Український модернізм: 1910-1930. Хмельницький: Галерея, 2006. С. 31-38.

13. Січинський В. Українська академія мистецтв // Українське мистецтво. Львів; Київ: [б. в.], 1926. Ч. 2. С. 51-53.

14. Січинський В. Юрій Нарбут // Українське мистецтво. Краків; Львів: Укр. вид-во, 1943. Вип. 2. C. 62 .

15. Соколюк Л. Живопис // Історія Українського мистецтва: у 5 т. / НАН України. ІМФЕ ім. М. Т. Рильського; голов. ред. Г. Скрипник, наук. ред. Т. Кара-Васильєва. Київ: ІМФЕ ім. М. Т. Рильського НАНУ, 2007. C. $64-85$.

16. Соколюк Л. Проблеми національного стилю в українському мистецтві першої третини XX століття // Вісник ХДАДМ. 2002. № 4. С. 3.

17. Щербаківський В. Деревляне будівництво і різьба на дереві // Українське мистецтво. Львів; Київ: [б. в.], 1913. № 1. С. 86.

\section{References}

1. Bilokin S. Kolektyvizm - pafos tvorchosti Mykhaila Boichuka // Obrazotvorche mystetstvo. 1988. \# 1. S. 22-24.

2. Burachek M. Koliektyvna tvorchist i shliakhy natsionalnoho mystetstva // Mystetstvo. 1920. \# 1. S. 6481.

3. Voloshyn L. Tvortsi ukrainskoho modernu: Olena Kulchytska // Obrazotvorche mystetstvo. 2005. \# 4. S. 47-49.

4. Vrona I. Puty sovremennoho ukraynskoho yskusstva // Revoliutsyia y kultura. 1928. \# 13. S. 60.

5. Holubets M. Maliarstvo // Ukrainske mystetstvo. Lviv; Kyiv: Shliakhy, 1918. S. 36.

6. Zelska-Darevych D. Ukrainski kultura i mystetstvo kriz viky // Ukrainskyi modernizm: 1910-1930. Khmelnytskyi: Halereia, 2006. S. 16-30.

7. Ernst F. Vystavka rysunku i hraviury // Bibliolohichni visti. 1926. \# 4. S. 110-111.

8. Prybieha L. Vikhy istorii ta sohodennia NAOMA. URL: http://naoma.edu.ua/ua/academy/storya/ (access date: 06.01.2019).

9. Kovalska L. Mykhailo Boichuk — uchytel ta mytets // Ukrainskyi modernizm 1910-1930. Khmelnytskyi: Halereia, 2006. S. 46-57.

10. Kovzhun O. Vasyl Kryzhanivskyi 1891-1926 // Ukrainske mystetstvo. Lviv; Kyiv: [b. v.], 1926. Ch. 3. S. 63-68.

11. Mykhailiv Yu. Heorhii Narbut // Zhyttia y revoliutsiia. 1926. \# 10. S. 79-92.

12. Mudrak M. Ukrainskyi avanhard // Ukrainskyi modernizm 1910-1930. Khmelnytskyi: Halereia, 2006. S. 31-38.

13. Sichynskyi V. Ukrainska akademiia mystetstv // Ukrainske mystetstvo. Lviv; Kyiv: [b. v.], 1926. Ch. 2. S. 51-53.

14. Sichynskyi V. Yurii Narbut // Ukrainske mystetstvo; vyp. 2. Krakiv; Lviv: Ukr. vyd-vo, 1943. S. 62. 
15. Sokoliuk L. Zhyvopys // Istoriia Ukrainskoho mystetstva: u 5 t. / NAN Ukrainy. IMFE im. M. T. Rylskoho; holov. red. H. Skrypnyk, nauk. red. T. Kara-Vasylieva. Kyiv: Instytut mystetstvoznavstva, folklorystyky ta etnolohii im. M. T. Rylskoho NANU, 2007. S. 64-85.

16. Sokoliuk L. Problemy natsionalnoho styliu v Ukrainskomu mystetstvi pershoi tretyny KhKh stolittia // Visnyk KhDADM. 2002. \# 4. S. 3.

17. Shcherbakivskyi V. Derevliane budivnytstvo i rizba na derevi // Ukrainske mystetstvo. Lviv; Kyiv: [b. v.], 1913. \# 1. S. 86.

Shevchenko M.

Interpreting the Traditions of Ukrainian Culture in the Works of the Early 20th Century Artists: Genesis of the National Style in Art

The issue of genesis of the national style in Ukrainian art of the early twentieth century was outlined in the atricle. The works of the artists revealing the creative potential were analyzed, works of the new stylistic manifestations in art were depicted, the ideological principles and creative style of artists in interpreting the traditions of Ukrainian culture, in particular folk art, were described within the context of the formation of the national style.

Keywords: Ukrainian national style, folk art, Ukrainian culture, painting, graphics, 20th century.

\section{Шевченко М.}

Интерпретация традиций украинской культуры в творчестве художников начала XX века: генезис национального стиля в искусстве

Рассмотрены вопросы генезиса национального стиля в украинском искусстве начала XX века. Выявлены темы, к которым обращались художники, раскрывая свой творческий потенциал, проанализированы произведения, которые подчеркивают новые стилевые проявления в искусстве, охарактеризованы мировоззренческие основы и творческая манера художников в интерпретации традиций украинской культуры, в частности народного искусства, в контексте формирования национального стиля.

Ключевые слова: украинский национальный стиль, народное искусство, украинская культура, живопись, графика, XX век. 